\title{
Sustainable waste management by production of activated carbon from agroforestry residues
}

AUTHORS:

Victor Ntuli ${ }^{1}$

Innocent Hapazari²

\section{AFFILIATIONS:}

'Department of Biology, National University of Lesotho, Roma, Lesotho

2Department of Chemistry and Chemical Technology, National University of Lesotho, Roma, Lesotho

\section{CORRESPONDENCE TO:}

Victor Ntuli

\section{EMAIL:}

ntally2001@yahoo.co.uk

\section{POSTAL ADDRESS:}

Department of Biology, National University of Lesotho, PO Roma 180, Lesotho

\section{DATES:}

Received: 02 Jan. 2012

Revised: 06 Aug. 2012

Accepted: 24 Aug. 2012

\section{KEYWORDS:}

activation; pyrolysis; characterisation; removal; adsorption

\section{HOW TO CITE:}

Ntuli V, Hapazari I. Sustainable waste management by production of activated carbon from agroforestry residues. S Afr J Sci. 2013;109(1/2), Art. \#1077, 6 pages. http://dx.doi. org/10.1590/sajs.2013/1077

(C) 2013. The Authors. Published under a Creative Commons Attribution Licence.
Agroforestry waste presents a problem for disposal and negatively impacts on the environment if left to rot or burn. The aim of this study was to reduce environmental problems associated with agroforestry waste by promoting the innovative use of such waste in the production of activated carbons (ACs) using a low-cost production technique, and ultimately delivering more affordable water and effluent treatment adsorbents. Four varieties of ACs from four different agroforestry materials - pine (Pinus contorta) cones (PC), Abies (Abies cilicica) seeds (AS), maple (Acer ginnala) seeds (MS) and peach (Prunus persica) stones (PS) - were prepared by single-step steam pyrolysis and characterised. The raw materials were evaluated for AC yield while the respective ACs were evaluated on the basis of iodine number, phenol specific area, ash content, $\mathrm{pH}$, moisture content and removal of metal ions, nitrates and sulphates from aqueous solution. The AC yields for PS, PC, AS and MS were found to be $23.0 \%, 18.0 \%, 17.8 \%$ and $14.6 \%$, respectively. The yield for PS (23\%) is within the specified commercial limits of $20 \%$ to $40 \%$. The phenol specific areas of the ACs ranged between $381 \mathrm{~m}^{2} / \mathrm{g}$ and $415 \mathrm{~m}^{2} / \mathrm{g}$ higher than the commercial lower limit $\left(300 \mathrm{~m}^{2} / \mathrm{g}\right)$ generally specified. The ACs also showed the capacity to remove heavy metal ions from their aqueous solutions. Removal of both nitrates and sulphates in raw water was greater than $50 \%$. Although no quantitative analysis has been performed to date, it is envisaged that the production of $A C$ from agroforestry wastes can contribute to the sustainable management of environmental pollution by these residues and the concomitant delivery of cheaper adsorbents.

\section{Introduction}

A large volume of agroforestry waste is one of the global environmental problems of our time. ${ }^{1}$ The waste tends to accumulate in water sources, resulting in pollution such as unpleasant odours, eutrophication, high levels of biological oxygen demand and chemical oxygen demand..$^{2-4}$ In response to rising costs associated with waste disposal and increasing environmental demands, the sustainable conversion of wastes into useful products is becoming increasingly important. ${ }^{5-7}$ Conventionally, agroforestry wastes are disposed of by thermal treatment, landfilling and decomposition. ${ }^{1}$ Despite numerous means of disposal, these wastes still have adverse impacts on the environment. ${ }^{6}$ Thermal treatment processes involve combustion which results in gaseous emissions $\left(\mathrm{CO}_{2}, \mathrm{CO}, \mathrm{C}_{n} \mathrm{H}_{m}, \mathrm{SO}_{x}, \mathrm{NO}_{x}\right.$, ashes, etc.), many of which are greenhouse gases; combustion is therefore a controversial method of waste disposal. ${ }^{8}$ On the other hand, landfill waste management commonly results in environmental odours, emission of greenhouse gases $-\mathrm{CH}_{4}$ and $\mathrm{CO}_{2}$ - and pollution of both underground and surface waters. ${ }^{9}$ The quest for environmentally friendly and sustainable ways of disposing of carbonaceous wastes, such as agroforestry wastes, has triggered research focusing on their potential as raw materials for the production of activated carbons.

Activated carbon (AC) is carbonaceous material with a highly developed internal surface area and porosity. The large surface area gives a high capacity for adsorbing chemicals from gases or liquids. ${ }^{10}$ The specific surface areas of ACs vary widely, with reported values ranging from $250 \mathrm{~m}^{2} / \mathrm{g}$ to over $2000 \mathrm{~m} / \mathrm{g}$, making them versatile adsorbents with a wide range of applications. ${ }^{10-14} \mathrm{~A}$ large volume of ACs is used in water treatment, in which ACs are added primarily to remove organics and other compounds that affect the taste and odour of the water. ${ }^{12-14}$ In some instances, removal of metals and biological elements may be intended. Other applications include industrial waste water and gas treatment; removal of compounds that affect colour, taste and odour in the food industry; recovery of metallic minerals such as gold from leached liquors in the mineral processing industry; medicinal and pharmaceutical uses; catalysis; and air filtration and conditioning. ${ }^{11-13}$

In developing countries, particularly in Africa, the costs associated with the production and/or importation of ACs for water treatment is very high. For example, 1 ton of coconut shell based activated carbon costs about USD950-1400 before shipment. ${ }^{14}$ This high cost is one of the many contributing factors to a lack of access to commercially treated water for a significant fraction of the population in developing countries. On the other hand, contamination of global water sources is worsening because of increasing industrial activities and population growth and the concomitant increase in waste generation. ${ }^{15}$ Recent research has established that $70-80 \%$ of all illnesses in developing countries is related to water contamination. ${ }^{15} \mathrm{AC}$ is considered a universal adsorbent for the removal of diverse types of pollutants from water; however, its use remains restricted by its relatively high cost, given the low per capita incomes in developing countries. ${ }^{11}$ The high cost of adsorbents also limits the capacity of industries to treat their effluents to required environmental standards before disposal - with some industries operating outside legal limits - thus exacerbating environmental pollution. Therefore, the need for development of sustainable, cheap and user-friendly water-treatment substances and/or technologies cannot be overemphasised. In particular, increasing demand for adsorption processes in the water-treatment industry is driving research into the production of AC from alternative precursors, such as industrial wastes and agricultural by-products. ${ }^{16}$

The potential of various agroforestry residues as water treatment adsorbents ${ }^{10,17}$ and as raw materials for production of $\mathrm{AC}^{11,13}$ has been a subject of investigation for more than two decades. Utilisation of single-step steam pyrolysis as a relatively cheap technique for producing AC from agroforestry residues has also been a subject of keen interest. ${ }^{10,16,18,19}$ Traditionally, commercial activation of carbon is conducted at temperatures above $800{ }^{\circ} \mathrm{C}$ in a 
mixture of steam and carbon dioxide ${ }^{16}$; and the main raw materials are coal, lignite, coconut shell and wood peat. ${ }^{20}$ Steam pyrolysis is a physical activation process in which the precursor material is heat-treated in the presence of steam to form AC. The physical activation process involves two main steps: carbonisation of the carbonaceous raw material to a carbonaceous char; and activation of the char in the presence of a suitable activating medium such as carbon dioxide, steam, air or their mixture. Carbonisation occurs between $400{ }^{\circ} \mathrm{C}$ and $800{ }^{\circ} \mathrm{C}$, while activation usually occurs between $600^{\circ} \mathrm{C}$ and $900{ }^{\circ} \mathrm{C} .{ }^{21}$ Several research studies have shown that steam activation is capable of delivering ACs of comparable properties to those of commercial ACs. . $11,13,14,18,19$

Although numerous studies have been devoted to investigating the potential of various agroforestry wastes as sources of $A C,{ }^{11,13,14,22,23}$ each particular material and method of production deserves special attention before any commercial viability is recommended. This specificity is necessary because both the raw material and the activation process determine the quality and the cost of producing the ACs. Currently, coconut shells are typical agroforestry residues used commercially in the production of activated carbons intended for drinking water treatment. ${ }^{14}$ The abundance of agroforestry waste makes it a potentially cheaper raw material for production of AC. Single-step steam pyrolysis, by virtue of its simplicity and low cost, is one of the most appropriate technologies for this purpose in developing countries. The aim of the present study was to evaluate the potential of converting agroforestry waste to commercial-grade AC, as an economic waste-management measure, using the low-cost single-step steam pyrolysis process.

\section{Materials and methods}

\section{Raw materials}

A total of $5 \mathrm{~kg}$ of each of pine (Pinus contorta) cones (PC), Abies (Abies cilicica) seeds (AS), maple (Acer ginnala) seeds (MS) and peach (Prunus persica) stones (PS) was collected around Roma, about $35 \mathrm{~km}$ southeast of Maseru, Lesotho. The raw materials were thoroughly cleaned by scraping off surface adherents and washing in distilled water before drying in an oven at $60^{\circ} \mathrm{C}$ for $24 \mathrm{~h}$.

\section{Preparation of activated carbons}

Production of activated carbons was done following the method described in Hapazari et $\mathrm{a}^{24}$. The dried raw materials were carbonised and activated using single-step steam pyrolysis. Samples $(250 \mathrm{~g})$ of each material were crushed into small pieces and placed in a stainlesssteel tray $(22 \mathrm{~cm} \times 15 \mathrm{~cm} \times 10 \mathrm{~cm})$ and inserted into a size 1 Gallenkamp box furnace (Griffin and George Limited, Leicestershire, England), fitted with a regulated steam generation system. Steam was generated by injecting water into the furnace at a rate of $20 \mathrm{~mL} / \mathrm{min}$, starting when the furnace temperature was at $100{ }^{\circ} \mathrm{C}$ until the end of the soak period (30 min). Softer raw materials (MS and AS) were treated at $500{ }^{\circ} \mathrm{C}$ while harder raw materials (PC and PS) were treated at $800^{\circ} \mathrm{C}$. The treatment temperatures were selected to ensure minimum ashing and good adsorption properties of the ACs. At the end of the soak period, samples were allowed to $\mathrm{Cool}$ in a furnace to $100^{\circ} \mathrm{C}$ before removing the ACs for washing. The ACs were washed with distilled water for 30 min at $60{ }^{\circ} \mathrm{C}$ to remove ash, then dried in the oven at $60^{\circ} \mathrm{C}$ for $24 \mathrm{~h}$ and weighed. The ACs were then ground to powder and sieved through an 80-mesh (0.177-mm) sieve.

\section{Characterisation of activated carbons}

The four experimentally produced ACs and a commercially available activated carbon (CAC) were characterised according to five parameters: phenol adsorption (which reflects the surface area of $A C$ ), iodine number (which indicates adsorption capacity), pH, ash content and moisture content.

\section{Phenol adsorption}

Phenol adsorption isotherms were determined and in turn were used to calculate specific surface area of the ACs. Five-point, single-adsorbate isotherms were constructed for a phenol concentration range of $0.2-$
$0.6 \mathrm{mM}$. Samples of approximately $0.1 \mathrm{~g} \mathrm{AC}$ were added to $100 \mathrm{~mL}$ adsorbate solution in 250-mL stoppered flasks. The flasks were then sealed and shaken at $100 \mathrm{rpm}$ in a temperature-controlled shaker bath (Gallenkamp, Griffin and George Limited) at $25{ }^{\circ} \mathrm{C}$ for $24 \mathrm{~h}$. The suspensions were then filtered through Whatman No.1 size 15 filter paper. Residual adsorbate concentrations were determined using a UV spectrophotometer (Shimadzu UV-160A, Sydney, Australia) at $270 \mathrm{~nm}$. The adsorption isotherms were analysed using the Langmuir aqueous phase adsorption model that applies Equation 1 (below) to establish best fit. ${ }^{25}$ The model assumes formation of a monolayer of the adsorbate on the carbon surface and is represented by Equation 1:

$$
q_{e}=\frac{b q_{m} C_{e}}{1+b C_{e}}
$$

Equation 1,

where $q_{e}$ is the amount of solute adsorbed on the carbon $(\mathrm{mol} / \mathrm{g}) ; C_{e}$ is the equilibrium concentration of solute (mol/L); $q_{m}$ is the Langmuir monolayer coverage constant (mol/g) and $b$ is the Langmuir adsorption coefficient. $q_{m}$ and $b$ can be derived from a linear plot of $1 / C_{e}$ against $1 / q_{e}$.

\section{lodine numbers}

lodine numbers were determined according to the standard procedures of the American Society for Testing and Materials. ${ }^{26}$

\section{$\mathrm{pH}$}

Slurries of the ACs were prepared by adding $0.2 \mathrm{~g} \mathrm{AC}$ samples to $100 \mathrm{~mL}$ distilled water in 250-mL flasks, and shaking at $200 \mathrm{rpm}$ using a shaker (Vacutec Cat $\mathrm{N}^{\circ} 10 \times 400 \times \times 2$ ) for $2 \mathrm{~h}$ under ambient conditions. The slurries were filtered and the $\mathrm{pH}$ of each filtrate was measured.

\section{Ash content}

For ash content, 2-g samples were ashed at $900{ }^{\circ} \mathrm{C}$ for $12 \mathrm{~h}$ in a furnace (Gallenkamp box) and the residue cooled to room temperature in a desiccator. The ash content was calculated as the weight ratio of the residues to the original sample.

\section{Moisture content}

A thermogravimetric method was used to determine moisture content. ${ }^{27}$

\section{Application of pine cone activated carbon}

Pine cone activated carbon (PCAC) was used to investigate the effectiveness of the experimental ACs for the removal of metal ions ( $\mathrm{Cd}$ (II), $\mathrm{Cu}(\mathrm{II}), \mathrm{Hg}$ (II), $\mathrm{Mn}$ (II) and $\mathrm{Pb}(\mathrm{II})$ ), nitrates and sulphates from water. The selection of PCAC was based on its superior performance, in terms of adsorption properties, compared to the other experimental ACs.

\section{Removal of nitrates and sulphates from water}

Analysis of nitrates and sulphates was done before and after treating water with activated carbon. A sample of untreated water $(100 \mathrm{~mL})$ was mixed with PCAC $(0.1 \mathrm{~g})$ in a $250-\mathrm{mL}$ Erlenmeyer flask. The mixture was shaken at $200 \mathrm{rpm}$ in a temperature-controlled shaker (Vacutec Cat $\left.\mathrm{N}^{\circ} 10 \times 400 \times \times 2\right)$ at $25 \pm 2{ }^{\circ} \mathrm{C}$ for $2 \mathrm{~h}$. After the specified time, the mixture was filtered using Whatman filter paper No. 1 size 15 to remove the carbon. Nitrates were determined using a UV spectrophotometer (Shimadzu UV 160 A, Sydney, Australia). The nitrate assay relied on a reaction between nitrate ions and sodium salicylate in the presence of tetraoxosulphate $(\mathrm{VI})$ acid medium to produce sodium nitrosalicylate, which is yellow in colour. The intensity of the yellow colour is directly proportional to the nitrate concentration in the sample. The minimum detectable concentration by this method is $0.01 \mathrm{mg} / \mathrm{L}$. Calibration standards ranging from $0.25 \mathrm{mg} / \mathrm{L}$ to $2.00 \mathrm{mg} / \mathrm{L}$ nitrate solution were prepared and were used to plot a standard curve. Absorbance of the sample was read on the spectrophotometer using quartz cuvettes at $420 \mathrm{~nm}$. The concentration of nitrates in each water sample was calculated from the calibration curve. ${ }^{28}$ 
For sulphate determination, calibration standards were prepared from sulphate solution stock ranging from $10 \mathrm{mg} / \mathrm{L}$ to $80 \mathrm{mg} / \mathrm{L}$ sulphate. The standards were then used to plot a calibration graph. A photometer (Spectronic 20 Genesys, Burlington, USA) was used to measure turbidity of the sulphates in the samples. A sample $(100 \mathrm{~mL})$ was mixed well into an Erlenmeyer flask with citrate buffer solution $(20 \mathrm{~mL})$ using a stirrer at constant speed. While stirring, a spoonful of barium chloride was added, after which stirring continued for $60 \mathrm{~s}$. After stirring, the solution was poured into an absorption cell of the photometer and turbidity was measured at $450 \mathrm{~nm}$. The concentration of sulphates in the sample was then calculated from the calibration curve.

\section{Removal of metal ions from water}

The removal of metal ions - Cd (II), $\mathrm{Cu}$ (II), $\mathrm{Hg}$ (II), $\mathrm{Mn}$ (II) and Pb (II) from water by the PCAC was determined using a flame atomic adsorption spectrophotometer (FAAS). All the adsorption experiments were carried out in triplicate using a batch adsorption technique. For each metal, a stock solution of metal ion concentration of $1000 \mathrm{mg} / \mathrm{L}$ was prepared by dissolving equivalent amounts of analytical reagent grade metal salts $\left(\mathrm{CdCl}_{2} \cdot \mathrm{H}_{2} \mathrm{O}, \mathrm{CuCl}_{2} .2 \mathrm{H}_{2} \mathrm{O}, \mathrm{HgCl}_{2}, \mathrm{MnCl}_{2} .4 \mathrm{H}_{2} \mathrm{O}\right.$ and $\mathrm{PbCl}_{2}$ ) in $250 \mathrm{~mL}$ deionised water. Experimental solutions were prepared by diluting stock solutions of (1) five single-element solutions of $50 \mathrm{mg} / \mathrm{L}$ metal ions and (2) a multi-element solution containing $7.14 \mathrm{mg} / \mathrm{L}$ of each of the metal ions. Approximately $0.1 \mathrm{~g}$ of PCAC was added to each of the six flasks containing $100 \mathrm{~mL}$ metal-ion solutions and continuously shaken for $3 \mathrm{~h}$ at room temperature. After the adsorption step, the aqueous phase was filtered through Whatman No.1 size 15 filter paper and the final concentration of metal ions was determined by FAAS (Varian Spectra AA-100, Melbourne, Australia).

\section{Statistical analysis}

Determinations of concentration were carried out in triplicate and standard errors were calculated for all results. Data obtained for the removal of metal ions were analysed by SPSS (version 16.0) using a one-tailed Student t-test to determine differences in the removal of metal ions between single- and multi-element solutions. $p<0.05$ was considered significant.

\section{Results and discussion}

\section{Suitability of raw materials}

The AC yields for MS, AS, PC and PS were found to be $14.6 \%, 17.8 \%$, $18.0 \%$ and $23.0 \%$, respectively (Figure 1). The yield for PS was not only the highest, but was also within the specified commercial range of $20-40 \%{ }^{29}$ Production of AC is dependent on the raw material used and the activation temperature. ${ }^{13}$ Generally, raw materials with hard structures are used for commercial AC production because they give higher yields. ${ }^{22}$ The hard raw materials contain a higher percentage of lignin as compared to other components, whereas soft raw materials have more cellulose and hemicellulose than lignin. ${ }^{30}$ Cellulose and hemicellulose are more susceptible than lignin to pyrolytic decomposition at temperatures $\geq 500{ }^{\circ} \mathrm{C}$. High activation temperatures $\left(\geq 800^{\circ} \mathrm{C}\right)$ produce $\mathrm{AC}$ of better adsorptive capacities, as shown by PCAC and PSAC. However, higher activation temperatures tend to lower $\mathrm{AC}$ yields as a result of endothermic reactions between carbon and steam. ${ }^{22,30}$

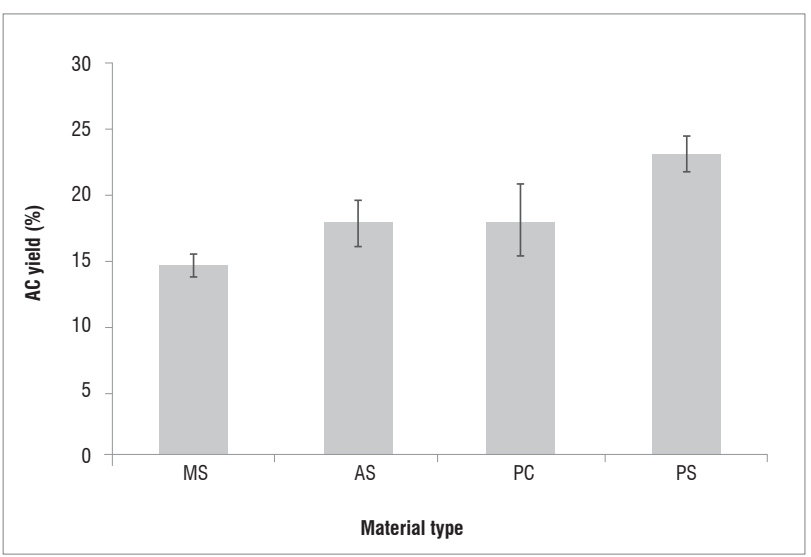

Figure 1: Percentage activated carbon (AC) yield for the raw materials investigated: maple seeds (MS), Abies seeds (AS), pine cones (PC) and peach stones (PS). The error bars shown are at a $5 \%$ confidence level.

\section{Properties of activated carbons}

Each of the ACs has its own characteristic properties and variation exists in the efficiency of removal of a range of impurities from water or any other media. Characterisation of the carbons is important in the formulation of a consistent quality carbon applicable for specific uses.

\section{Ash content and $\mathrm{pH}$}

Ash contents for PCAC, MSAC, PSAC and ASAC were $3.03 \%, 3.90 \%$, $3.03 \%$ and $5.35 \%$, respectively (Table 1). The ash content is directly related to the $\mathrm{pH}$ of $\mathrm{AC}$ and the measured $\mathrm{pH}$ values were $8.43,8.64$, 8.58 and 9.76 , respectively. A basic $\mathrm{pH}$ is expected because the ash consists mainly of salts and oxides of the chemical elements dominating plant tissue, including calcium salts, alkali carbonates and silica. Fe, $\mathrm{Al}, \mathrm{Mn}$ and $\mathrm{Mg}$ are present in small amounts. The $\mathrm{pH}$ values are fairly comparable to $\mathrm{pH}$ values reported by Budinova et al. ${ }^{31}$ for ACs from olive seeds, coconuts, cherry stones, peach stones, apricot stones and Moringa husks, which ranged between 8 and 12. High pH values are indicative of soluble inorganic material, which, for specific uses such as medical and pharmaceutical applications, may need to be removed for the carbon to be used.

Table 1: Characteristics of the experimental carbons and a commercially available activated carbon

\begin{tabular}{|c|c|c|c|c|c|c|c|}
\hline Carbon sample & $\begin{array}{c}\text { Ash content } \\
(\%)\end{array}$ & $\mathrm{pH}$ & $\begin{array}{l}\text { Moisture } \\
\text { content } \\
(\%)\end{array}$ & \begin{tabular}{|c|} 
Water solubility \\
$(\%)$ \\
\end{tabular} & $\begin{array}{l}\text { Solubility in } \\
0.2 \mathrm{M} \mathrm{HCI} \\
(\%)\end{array}$ & $\begin{array}{l}\text { Iodine value } \\
(\mathrm{g} / 100 \mathrm{~g}) \\
\end{array}$ & $\begin{array}{l}\text { Phenol specific } \\
\text { area } \\
\qquad\left(\mathrm{m}^{2} / \mathrm{g}\right)\end{array}$ \\
\hline ASAC & $5.35 \pm 0.13$ & $9.76 \pm 0.28$ & $0.59 \pm 0.06$ & $5.0 \pm 0.16$ & $4.7 \pm 0.18$ & $52.2 \pm 0.23$ & $381 \pm 0.66$ \\
\hline MSAC & $3.90 \pm 0.09$ & $8.64 \pm 0.17$ & $0.68 \pm 0.05$ & $3.0 \pm 0.19$ & $4.0 \pm 0.11$ & $61.4 \pm 0.07$ & $388 \pm 0.45$ \\
\hline PCAC & $3.03 \pm 0.16$ & $8.34 \pm 0.10$ & $0.82 \pm 0.08$ & $2.3 \pm 0.10$ & $2.7 \pm 0.03$ & $100.3 \pm 0.11$ & $415 \pm 0.10$ \\
\hline PSAC & $3.03 \pm 0.11$ & $8.58 \pm 0.25$ & $1.19 \pm 0.03$ & $2.5 \pm 0.24$ & $2.2 \pm 0.14$ & $73.6 \pm 0.20$ & $399 \pm 0.06$ \\
\hline CAC & $2.00 \pm 0.22$ & $8.20 \pm 0.13$ & $0.11 \pm 0.03$ & $1.8 \pm 0.04$ & $1.0 \pm 0.03$ & $172.9 \pm 0.32$ & $600 \pm 0.50$ \\
\hline
\end{tabular}

ASAC, activated carbon produced from Abies seeds; MSAC, activated carbon produced from maple seeds; PCAC, activated carbon produced from pine cones; PSAC, activated carbon produced from peach stones; $C A C$, commercial activated carbon 


\section{Moisture content}

The prepared ACs exhibited low moisture contents of $0.59-1.19 \%$, which are ideal for storage (Table 1). Generally, the recommended AC storage moisture content is less than $3 \%{ }^{32}$ The higher the moisture content, the more susceptible the carbon is to fungal growth, thus the lower the storage and shelf-life of activated carbon. High moisture contents encourage the growth of AC microorganisms (fungi) within the macropores and micropores of the AC, blocking the pores and thereby reducing the adsorptive capacity of the carbon. ${ }^{27}$

\section{lodine value}

The iodine value is a convenient indicator of carbon adsorption activity and is even relied upon in the water treatment industry for selection of $\mathrm{AC}$ from suppliers. The experimental carbons gave iodine values ranging from $52.2 \mathrm{~g} / 100 \mathrm{~g}$ to $100.3 \mathrm{~g} / 100 \mathrm{~g}$, while the CAC gave an iodine value of $172.9 \mathrm{~g} / 100 \mathrm{~g}$ (Table 1). The experimental carbons exhibit inferior adsorption activities relative to CAC with the best of them, $\mathrm{PC}$, being approximately 1.7 times less than CAC. However, the activities are technically viable and are not necessarily unique. Elsewhere, comparable results have been reported on evaluating ACs from agricultural wastes such as almond shells, cherry stones and peach stones, in which the iodine values ranged from $75 \mathrm{~g} / 100 \mathrm{~g}$ to $145 \mathrm{~g} / 100 \mathrm{~g} \cdot{ }^{19}$

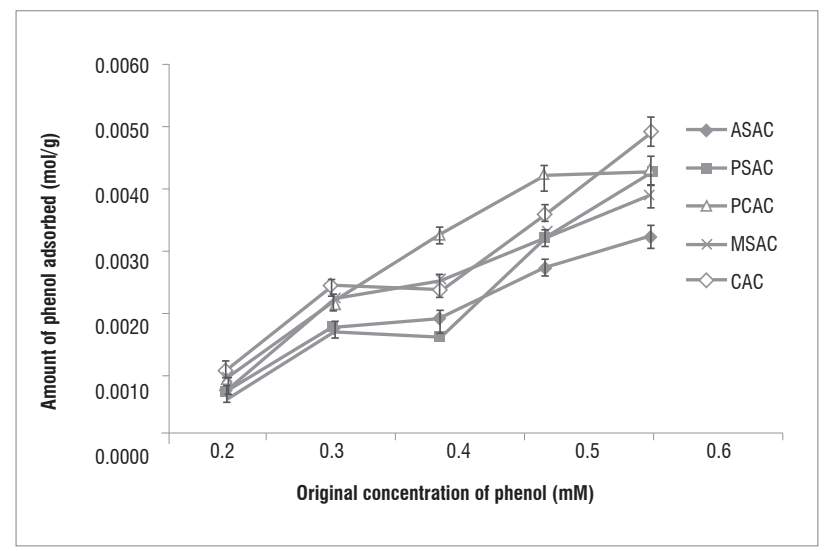

Figure 2: Phenol adsorption isotherms of the four experimental carbons pine cone activated carbon (PCAC), maple seed activated carbon (MSAC), peach stone activated carbon (PSAC) and Abies seed activated carbon (ASAC) - and a commercially available activated carbon (CAC). Results shown are mean values \pm standard errors from three separate experiments at a $5 \%$ confidence level.

\section{Specific surface area}

Adsorption isotherms (Figure 2) were used to assess the adsorptive capacity of carbons by estimating the surface area available for a monolayer of a molecule of phenol. A higher phenol specific area indicates a large micropore volume of the carbon. The phenol specific areas ranged between $318 \mathrm{~m}^{2} / \mathrm{g}$ (for PSAC) and $415 \mathrm{~m}^{2} / \mathrm{g}$ (for PCAC). The shape of the adsorption isotherms can provide preliminary qualitative information on the adsorption mechanism and on the porous structure of the carbons. At low phenol concentrations, less than $0.3 \mathrm{mM}$, all isotherms present a sharp increase typical of adsorption taking place by primary filling of micropores. Between $0.3 \mathrm{mM}$ and $0.4 \mathrm{mM}$, curves exhibit a levelling off (or adsorption equilibrium), presumably marking the end of primary filling of micropores. Above $0.4 \mathrm{mM}$, the curves increase sharply again, which presumably shows the onset of secondary filling of super-micropores. Based on the shape of the graphs in Figure 2, the characteristics resemble Langmuir isotherms, also reported by Ntuli ${ }^{18}$, Okeola and Odebunmi ${ }^{33}$ and Aloko and Adebayo. ${ }^{34}$ The surface area of AC is generally proportional to its adsorptive capacity. Surface area is dependent on the mass removed during activation of the carbon, which creates pores in the material. The surface of $A C$ is also influenced by the ash content of the raw material. A high ash content is indicative of high levels of non-carbonaceous matter (impurities) that tend to block the pores during activation, thus lowering the surface area. All raw materials used in this study exhibited low ash contents, which are ideal for attainment of large surface areas in their AC derivatives.

\section{Adsorption of nitrates and sulphates}

The PCAC adsorbed both nitrates and sulphates in water and these were reduced from $2.1 \mathrm{mg} / \mathrm{L}$ to $0.8 \mathrm{mg} / \mathrm{L}$ and $680 \mathrm{mg} / \mathrm{L}$ to $200 \mathrm{mg} / \mathrm{L}$, respectively (Table 2; Figure 3). Nitrates and sulphates pose a problem of eutrophication in the aquatic ecosystem, which results in bad odours in water if found exceeding the maximum limit of $600 \mathrm{mg} / \mathrm{mL}^{15}$

Table 2: $\quad$ Nitrate and sulphate values $(\mathrm{mg} / \mathrm{L})$ for untreated water and water treated with pine cone activated carbon

\begin{tabular}{l|l|l}
\hline \hline Parameter & Untreated & Treated \\
\hline \hline Nitrates & $2.1 \pm 0.05$ & $0.8 \pm 0.02$ \\
\hline Sulphates & $680 \pm 10.5$ & $200 \pm 3.1$ \\
\hline
\end{tabular}

Generally, percentage adsorption of impurities is proportional to the surface area of AC. ${ }^{14,27}$ PCAC demonstrated a well-developed surface area (internal pore structure) as removal of nitrates and sulphates was above $50 \%$ (Figure 3 ).

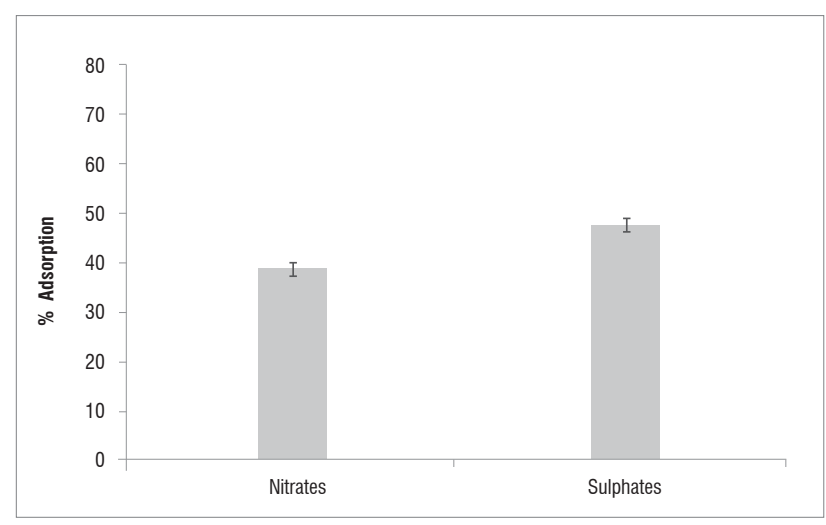

Figure 3: Percentage adsorption of nitrates and sulphates from water by pine cone activated carbon. The error bars shown are at a $5 \%$ confidence level.

The high adsorption capacity shows that PCAC has a potential application in waste water and water-treatment plants. The same can also be said about the other experimental carbons because their adsorption characteristics are closely comparable to PCAC, albeit slightly lower.

\section{Adsorption of metal ions}

Although we did not investigate the parameters known to influence the adsorption process, such as contact time, $\mathrm{pH}$ and adsorbent dose, the results still present a positive illustration of the capacity of the tested ACs to adsorb metals from water (Figure 4). The differences in percentage removal of specific elements from single-element and the multi-element solutions can be attributed to the competition for active sites by the elements. In a single-element solution, only one element is available for adsorption by the active sites, while in a multi-element solution, the five elements compete for the active sites for adsorption at constant adsorbent dose. This competition resulted in significantly lower 
percentage adsorptions $(p<0.05)$ from the multi-element solution than from the single-element solutions.

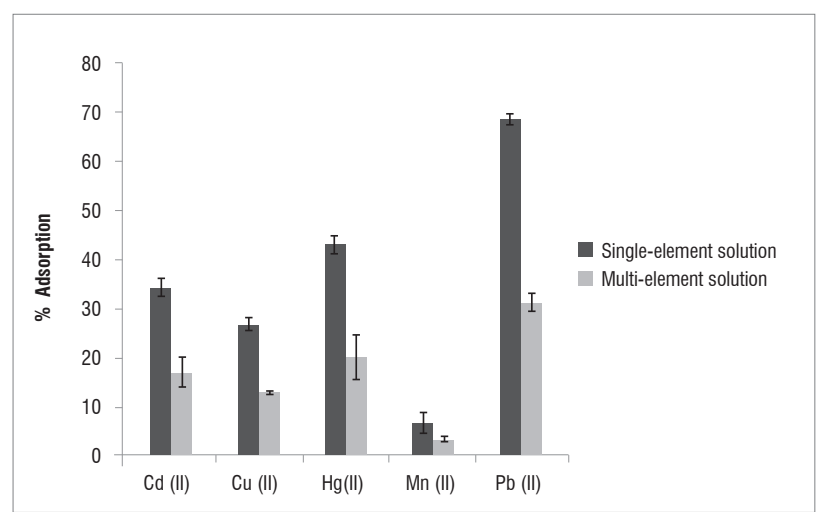

Figure 4: Percentage adsorption values for metal ions in single-element and multi-element solutions. The error bars shown are at a $5 \%$ confidence level. There was a significant difference in percentage adsorption between single-element and multielement solutions $(p<0.05)$.

\section{Conclusions}

We demonstrated the technical potential of using a combination of agroforestry wastes and the single-step steam pyrolysis technique to produce activated carbons of acceptable functional properties. We also envisaged that the application of such a process at an industrial scale could contribute towards agroforestry waste reduction in the environment as well as deliver economically competitive ACs. On the basis of AC yields, the use of PS gave a commercially viable yield of $23.0 \%$ (above the commercially recommended lower limit of 20\%). Two other raw materials - AS and PC - gave yields of $17.8 \%$ and $18.0 \%$, which were scattered around the $20 \%$ minimum limit, making them also promising raw materials for commercial production. All the investigated agroforestry wastes gave ACs of good quality based on the analysed characteristics. The ACs were by and large suitable for drinking water treatment, as well as any other application of comparatively less stringent requirements.

\section{Acknowledgements}

This research would not have been accomplished without the Research Grant provided by the National University of Lesotho. We also thank the Department of Chemistry \& Chemical Technology and the Department of Biology for the provision of laboratory facilities and various other forms of support.

\section{Authors' contributions}

V.N. and I.H. contributed equally to the experimental design, data collection and writing of the manuscript.

\section{References}

1. Gholz HL, editor. Agroforestry: Realities, possibilities and potentials. Dordrecht, the Netherlands, Martinus Nijhoff Publishers in cooperation with ICRAF; 1987

2. Mizuno 0, Dinsdale R, Hawkes FR, Hawkes DL, Noike T. Enhancement of hydrogen production from glucose by nitrogen gas sparging. Bioresour Technol. 2000;73(1):59-65. http://dx.doi.org/10.1016/S09608524(99)00130-3

3. Lay JJ, Lee YJ, Noike T. Feasibility of biological hydrogen production from organic fraction of municipal solid waste. Water Resour. 1999;33(11):2579-2586.

4. Kanu I, Achi OK. Industrial effluent and their impact on water quality of receiving rivers in Nigeria. J Appl Technol Env Sanitation. 2001;1(1):75-86.
5. Zhang R, El-Mashad HM, Hartman K, et al. Characterization of food waste as feedstock for anaerobic digestion. Bioresour Technol. 2007;98(4):929-935. http://dx.doi.org/10.1016/j.biortech.2006.02.039

6. Kwon SH, Lee DH. Evaluation of Korean food waste composting with fedbatch operations. Process Biochem. 2004;39(9):1183-1194. http://dx.doi. org/10.1016/S0032-9592(03)00233-4

7. Scragg A. Environmental biotechnology. Essex: Longman; 1999.

8. Momirlan M, Vezirogu T. Recent directions of world hydrogen production. Renewable Sustainable Energy Rev. 1999;3(2-3):219-231. http://dx.doi. org/10.1016/S1364-0321(98)00017-3

9. Rao KJ, Shantaram MV. Soil and water pollution due to open landfills. Sustainable landfill management; 2003 Dec 3-5; Chennai, India. p. 27-38.

10. Zanzi R, Bai X, Capdevila P, Björnbom E. Pyrolysis of biomass in presence of steam for preparation of activated carbon, liquid and gaseous products. Proceedings of the 6th World Congress of Chemical Engineering; 2001 Sept 23-27; Melbourne, Australia.

11. Bhatnagar A, Sillanpää M. Utilization of agro-industrial and municipal waste materials as potential adsorbents for water treatment $-A$ review. Chem Eng J. 2010;157(2-3):277-296. http://dx.doi.org/10.1016/j.cej.2010.01.007

12. Adinata D, Daud WMAW, Aroua MK. Preparation and characterization of activated carbon from palm shell by chemical activation with $\mathrm{K}_{2} \mathrm{CO}_{3}$. Bioresour Technol. 2007;98(1):145-149. http://dx.doi.org/10.1016/j. biortech.2005.11.006

13. Ioannidou 0 , Zabaniotou $A$. Agricultural residues as precursors for activated carbon production - A review. Renewable Sustainable Energy Rev. 2007;11(9):1966-2005. http://dx.doi.org/10.1016/j.rser.2006.03.013

14. Ahmedna M, Marshall WE, Rao M. Production of granular activated carbon from select agricultural by-products and evaluation of their physical, chemical and adsorption properties. Bioresour Technol. 2000;71(2):113-123. http:// dx.doi.org/10.1016/S0960-8524(99)00070-X

15. World Health Organization. Global water supply and sanitation assessment report. Geneva: WHO; 2007.

16. Miguel GS, Fowler GD, Sollars CJ. A study of the characteristics of activated carbons produced by steam and carbon dioxide activation of waste tyre rubber. Sci Total Environ. 2006;366(2-3):409-426.

17. Abia AA, Igwe JC. Sorption kinetics and intraparticulate diffusivities of $\mathrm{Cd}$, $\mathrm{Pb}$ and $\mathrm{Zn}$ ions on maize cob. Afr J Biotechnol. 2003;4(6):509-512.

18. Ntuli V. Characterisation of activated carbon prepared from agroforestry wastes and applicaton in water treatment [MSc dissertation]. Harare: University of Zimbabwe; 2007.

19. Warhurst AM, McConnachie GL, Pollard SJT. Characterisation and applications of activated carbon produced from Moringa oleifera seed husks by single step steam pyrolysis. Water Resour. 1997;31(4):759-766.

20. Bansode RR, Losso JN, Marshal WE, Rao RM, Portier RJ. Adsorption of metal ions by pecan shell based granula activated carbon. Bioresour Technol. 2002;89(2):115-119. http://dx.doi.org/10.1016/S0960-8524(03)00064-6

21. Cetin E, Moghtaderi B, Gupta R, Wall TF. Influence of pyrolysis conditions on the structure and gasification reactivity of biomass chars. Fuel. 2004;83(16):2139-2150. http://dx.doi.org/10.1016/j.fuel.2004.05.008

22. Aygun A, Yenisoy S, Duman I. Production of granular activated carbon from fruit stones and nutshells and evaluation of their physical, chemical and adsorption properties. Microporous Mesoporous Mater. 2003;66(2-3):189_ 195. http://dx.doi.org/10.1016/j.micromeso.2003.08.028

23. Girgis BS, Yunis SS, Soliman AM. Characterisation of activated carbon from pecan hulls in relation to conditions of preparation. Mater Lett. 2000;57(1):164-172. http://dx.doi.org/10.1016/S0167-577X(02)00724-3

24. Hapazari I, Ntuli V, Parawira W. Evaluation of single-step steam pyrolysisactivated carbons from Lesotho agro-forestry residues. Tanz J Sci. 2011;37:120-128.

25. McConnachie G, Mtawali A, Young R. Design aspects of hydraulic flocculates. Proceeding of the 20th WEDC Conference: Affordable Water Supply and Sanitation; 1994; Colombo, Sri Lanka. p. 284-288. 
26. ASTM D 4607-86: Standard test method for determination of iodine number of activated carbon. In: Annual Book of ASTM standards. Philadelphia, PA: ASTM; 1994; p. 15.01.

27. Kadirvelu K, Kavipriya M, Karthika C, Radhika M, Vennilamani N, Pattabi S. Utilization of various agricultural wastes for activated carbon preparation and application for the removal of dyes and metal ions from aqueous solutions. Bioresour Technol. 2003;87(1):129-132. http://dx.doi.org/10.1016/ S0960-8524(02)00201-8

28. Gheysari MM, Houdaji M, Abdelahi A. Assessment of nitrate pollution of groundwater in south-east of Isfahan region. J Env Studies. 2007;3(42):43-50.

29. Food and Agriculture Organization (FAO). Industrial charcoal making: Volume 63. Rome: FAO; 1985.

30. Murayama H, Moriyama N, Mitobe H, Mukai H, Takase $\mathrm{Y}$, Shimizu K, et al. Evaluation of activated carbon fibre filter for sampling of organochlorine pesticides in environmental water samples. Chemosphere. 2003;52(5):825833. http://dx.doi.org/10.1016/S0045-6535(03)00312-6
31. Budinova TK, Gergova KM, Petrov NV, Minkova VN. Removal of metal ions from aqueous solution by activated carbons obtained from different raw materials. J Chem Technol Biotechnol. 1994;60(2):177-182. http://dx.doi. org/10.1002/jctb.280600210

32. Helleur R, Popovic N, Liu D, Ikura M. Characterisation and potential application of pyrolytic char from ablative pyrolysis of used tyres. J Anal Appl Pyrol. 2001;58-59(1):813-824. http://dx.doi.org/10.1016/S01652370(00)00207-2

33. Okeola FO, Odebunmi EO. Freundlich and Langmuir isotherms parameters for adsorption of methylene blue by activated carbon derived from agrowastes. Adv Nat Appl Sci. 2010;4(3):281-288.

34. Aloko DF, Adebayo GA. Production and characterization of activated carbon from agricultural wastes (rice-husk and corn-cob). J Eng Appl Sci. 2007;2(2):440-444. 